\title{
Research on the Paths of Cultivating College Students' Information Literacy
}

\author{
Gemin Li \\ Jilin Agricultural University, Changchun 130118, China \\ 308420502@qq.com
}

\begin{abstract}
Information literacy has become a basic and essential literacy for modern people living in information society to adapt to the development of information society. In this paper, the theoretical analysis and empirical research methods are used to study the development of College Students' information literacy. In this paper, the self-made questionnaire of university students' information literacy is used, 400 students from 4 universities in Heilongjiang are selected as the research object. Analyze the factors for information literacy of College students, and get three dimensions of university students' information literacy: information ability, information consciousness, information idea and ethics. Research findings show that College students information literacy has an obvious difference in gender, grade, students, having a computer or not and having published articles or not; parts of College students are characterized by lack of information ability, weak information consciousness, weak information concept and information ethics. The questionnaire of College students' information literacy training is applied. Select 201 universities students as the research object, using excel to analyze College and university students' information literacy training situation. It is concluded that: the cultivation of information literacy didn't be attached enough importance by relevant departments, informatization construction and multimedia teaching has not been paid enough attention, information literacy training curriculum is not ideal, and the College teachers lack information literacy. For solving the problem, this paper proposes the method of focusing on improving the level of information literacy of teachers in Colleges and universities, reforming information literacy curriculum, and constructing the new teaching mode.
\end{abstract}

Keywords: Higher education; College students; Information literacy; Information literacy training strategy.

\section{Introduction}

Compared with foreign famous universities, Chinese universities are still backward relatively in cultivating students' information literacy that cultivating way is relatively simple and there is a big gap between the requirements of information society on information literacy of College students. As China's comprehensive national strength increases and the social construction of information infrastructure continuously develops, information technology has penetrated into all aspects of people's study, work and life [1]. At this time, if individuals do not have the information literacy as the backing, they will be trapped in confusion in the information society, even because a series of problems, such as College student's crime information, research students plagiarized papers and so on. These phenomena are enough to explain that the information literacy, as one of the basic ability of talents in twenty-first Century, is increasingly affecting the development process of social civilization. This study, based on Colleges and universities, take information literacy as the background, does a questionnaire survey on College students, and does a systematical analysis on university students' information literacy and its cultivation present situation through the literature analysis and comparative analysis, find out the existing problems [2]. And actively explore countermeasures and suggestions for improving the information literacy of students in Colleges and universities in China, and promote the academic circles to the subject, which causes the social attention to College students information literacy training from all walks of life, promotes the comprehensive upgrade of the information literacy education for university students, and accelerates the pace of higher education reform in the 21 st century. 


\section{Current Situation and Analysis of College Students' Information Literacy and Its Cultivation}

Select students in Harbin University of Commerce, Harbin University of Science and Technology, Harbin Normal University and Heilongjiang University these 4 Colleges as the research object. Randomly distribute questionnaire in the four universities, each school for 110 copies, and issued a total of 440 copies, 400 valid questionnaires, the recovery rate was $90.09 \%$, and the proportion of boys and girls is 170:230 [3]. The test is shown in table 1 .

Table 1 Composition of the tested

\begin{tabular}{|l|c|c|c|}
\hline \multicolumn{2}{|c|}{ Number of students } & Proportion (\%) & $42 \%$ \\
\hline Gender & Male & 170 & $58 \%$ \\
\hline Grade & Female & 230 & $13 \%$ \\
\hline \multirow{3}{*}{} & Freshman & 50 & $14 \%$ \\
\hline & Sophomore & 60 & $23 \%$ \\
\hline College & Junior & 90 & $28 \%$ \\
\hline & Senior & 120 & $22 \%$ \\
\hline & Graduate students & 80 & $25 \%$ \\
\hline & Harbin University of Commerce & 100 & $25 \%$ \\
\hline Place of origin & Tarbin University of Science and & 100 & $25 \%$ \\
\hline & Harbin Normal University & 100 & $25 \%$ \\
\hline
\end{tabular}

After analyzing the elements of information literacy, we study and analyze several important issues in the questionnaire.

(1) Information ability

Table 2 Organize the information obtained and form their own opinion

\begin{tabular}{|c|c|c|c|c|}
\hline & Frequency & Percentage & $\begin{array}{c}\text { Effective } \\
\text { percentage }\end{array}$ & $\begin{array}{c}\text { Accumulated } \\
\text { percentage }\end{array}$ \\
\hline Completely unmatched & 3 & 0.7 & 0.7 & 0.7 \\
\hline Comparatively unmatched & 36 & 8.7 & 8.7 & 9.4 \\
\hline Uncertain & 10 & 24.6 & 24.6 & 36.1 \\
\hline Comparatively matched & 213 & 56.8 & 56.8 & 90.8 \\
\hline Completely matched & 38 & 9.2 & 9.2 & 100.0 \\
\hline
\end{tabular}

In view of the students' attitude towards the use of information, it is investigated and analyzed that the information can be organized and form their own opinions or not. From the table 2, it can be seen that $34.10 \%$ of the students cannot be a good collection of information to organize and form their own opinion. The aim and function of organization information is information ordering [4]. Disorderly information does not help students to know the nature of things, but orderly information, because it more obviously reflects the contact of the nature of things, this is more helpful for students to store, search, evaluation, utilization, spread, develop and create information [5]. Thus, the organization of information is very important for College students. However, at present, more than one third of the students cannot well organize together and form their own opinions with the collected information, so in China's colleges and universities, it is necessary to take effective measures to change the status.

(2) Information awareness

In terms of the information consciousness of College students, the situation of knowing about related websites of their own professionals is investigated and analyzed. It can be seen from table 3 that $65.2 \%$ of the students are not very understanding of their professional-related sites. Only $1 / 3$ of College students have a better understanding of their professional web sites. 
Table 3 Knowing about the related websites of their own professionals or not

\begin{tabular}{|c|c|c|c|c|}
\hline & Frequency & Percentage & $\begin{array}{c}\text { Effective } \\
\text { percentage }\end{array}$ & $\begin{array}{c}\text { Accumulated } \\
\text { percentage }\end{array}$ \\
\hline Completely unmatched & 43 & 10.4 & 10.4 & 10.4 \\
\hline Comparatively unmatched & 141 & 34.1 & 34.1 & 44.4 \\
\hline Uncertain & 86 & 20.8 & 20.8 & 65.2 \\
\hline Comparatively matched & 120 & 30.7 & 30.7 & 95.9 \\
\hline Completely matched & 10 & 4.1 & 4.1 & 100.0 \\
\hline
\end{tabular}

(3) Information concept and information ethics

Table 4 Knowing about information literacy or not

\begin{tabular}{|c|c|c|c|c|}
\hline & Frequency & Percentage & $\begin{array}{c}\text { Effective } \\
\text { percentage }\end{array}$ & $\begin{array}{c}\text { Accumulated } \\
\text { percentage }\end{array}$ \\
\hline Completely unmatched & 50 & 14.0 & 14.0 & 14.0 \\
\hline Comparatively unmatched & 90 & 22.7 & 22.7 & 36.7 \\
\hline Uncertain & 173 & 42.3 & 42.3 & 79.0 \\
\hline Comparatively matched & 80 & 19.3 & 19.3 & 98.3 \\
\hline Completely matched & 7 & 1.7 & 1.7 & 100.0 \\
\hline
\end{tabular}

Knowing about the concept and meaning of information literacy or not is investigated and analyzed in terms of the information concept of College students. It can be seen from table 4 that $79 \%$ of the students is not very clear about the concept of information literacy and its definition, and there are $36.7 \%$ of the students even do not know what information literacy is. Only $1.7 \%$ of the students have a complete understanding of the concept and definition of information literacy [6].

In addition, in order to better know about the current situation of information literacy of College students, in allusion to Colleges' efforts on cultivating information literacy, we do investigation from whether there is literature retrieval course or information literacy related courses, the main way of cultivating information literacy, and the offered forms of school document retrieval courses or related courses these three aspects.

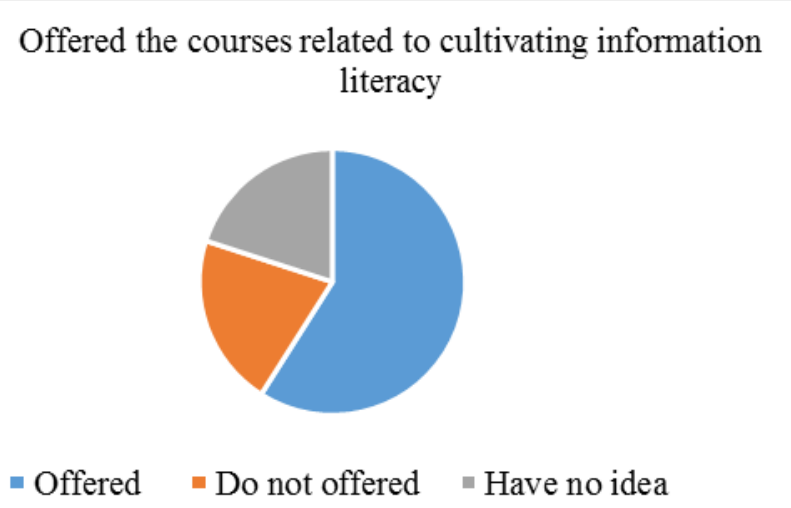

Figure 1 Whether Colleges offered the courses related to cultivating information literacy or not 
Main way of cultivating information literacy

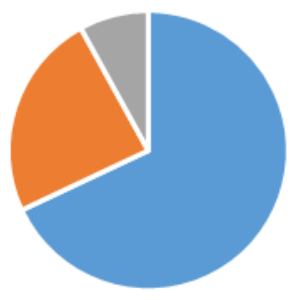

- Offered computer application courses

- Offered document retrieval course

- Comprehensive training

Figure 2 Main way of cultivating College students' information literacy

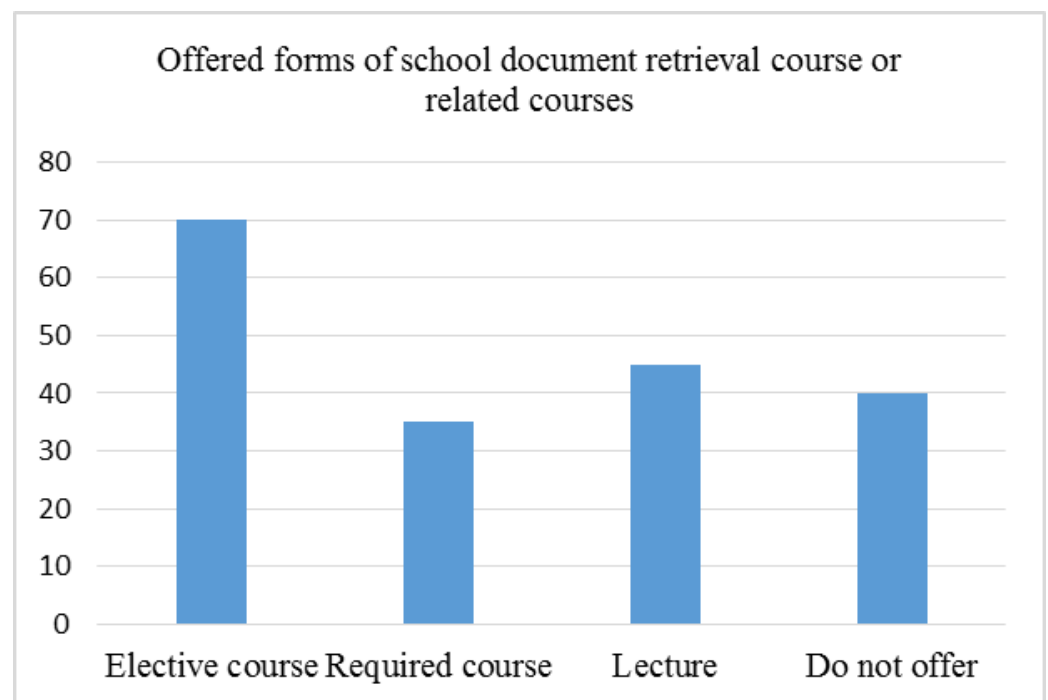

Figure 3 Offered forms of school document retrieval course or related courses

\section{Countermeasures and Suggestions to Cultivate the Information Literacy of College Students}

\subsection{Improving the Level of Information Literacy of Teachers in Colleges}

College teachers' information literacy is the basic premise and important guarantee for college students' information literacy. Information literacy of students is greatly relevant to teachers' teaching and education. Many students don't know the concept of information literacy or the meaning of information technology, which is related to teachers' teaching. Therefore, it is supposed to improve the information literacy of university teachers, and provide support for the improvement of information literacy of college students.

In order to meet the development requirements of education informatization, first of all, it is necessary to include "information literacy education" in the training of university teachers. Teachers' information literacy training mainly includes application of specialized information technology and strengthening of information consciousness. The application of information technology mainly intends let them master the skills of a computer network and learn to use some software; the most important part of the information literacy training is to strengthen teachers' information consciousness, changing the concept of education, and training and strengthening their information awareness [7]. Develop and use online resources for teaching services, to create a good learning environment for information literacy, and guide students to use the information on the Internet for learning services, comprehensive understand the students, creatively solve the problems. 


\subsection{Reforming Information Literacy Curriculum}

The first step in the reform of information literacy curriculum in universities should be encouraging teachers to prepare information literacy related materials. Material should be written according to the specific circumstances of the school, and it should also be related to the teachers, hardware conditions. The preparation of information literacy teaching materials is included into the process of scientific research in Colleges. Many colleges at present have no specialized information literacy curriculum, but similar courses, the literature retrieval course. But the literature retrieval course has many shortcomings in offering way, teaching objectives, and teaching content and so on, which cannot support the cultivation of college students' information literacy. Information literacy related courses cannot be isolated. Only the information literacy related courses are integrated into the professional course can we better play its role? For students of different grades, it can be layered to cultivate their information literacy. Cultivation of college students' information literacy should be a step-up process. According to the needs of the students of different grades, offer information literacy curriculum, and through the coordination and complement of the courses with each other, realize the goal of cultivating information literacy of university.

\subsection{Constructing the New Teaching Mode}

Through the investigation, we know that current college students are not active and positive in concerns and needs of information. In addition, for the CNKI China Journal Net this resource gathering, there is also a great resource waste phenomenon. Therefore, colleges and universities in the teaching content should increase related knowledge. By imparting knowledge of relevant information to stimulate and cultivate students' information consciousness, improve the degree of students' attention to the information and sensitivity, enhance the conscious level of their obtaining, analyzing, judging and using the information. In addition, university teachers should consciously guide the students to concern China Journal Net this resource treasure to improve students' initiative and enthusiasm in the attention to the information, and more effectively cultivate students' information consciousness.

\section{Conclusion}

Information is an important factor to promote the development of social economy, science and technology as well as the development of human life in the era of rapid development of information. The cultivation of information literacy is an issue with the times. At present, many countries in the world have taken the cultivation of information literacy as an important part of personnel training. In twenty-first Century, the talent needed is an innovative talent with the ability of self-access to knowledge and self-renewal of knowledge. Only by improving the information literacy of college students can it be possible to enable students to get a more comprehensive development [8]. Information literacy is the basic literacy that every college student should have. It is the goal of higher education to improve the level of information literacy of college students, to cultivate all-round development and innovative ability of high quality personnel. This paper, through the analysis of current situation of information ability, information awareness, information concept and information ethics, conclude that the college students are different in gender, grade, place of origin and they lack information ability, information consciousness, and their information concept and information ethics are not high. For better solving this problem, this paper proposes the measurements of improving the level of information literacy of teachers in colleges, reforming information literacy curriculum, and constructing the new teaching mode, so as to make college students become innovative talents and lifelong learners.

\section{References}

[1] Clarke K, Hazard G, Horst S J. The role of a required information literacy competency exam in the first college year: What test data can, cannot, and might reveal (Lightning Talk) [J]. 2014. 
[2] Radloff J D, Maybee C, Slebodnik M, et al. Why are we doing this? The role of personal relevance in developing biological information literacy using cyber Peer-led Team Learning $[\mathrm{J}]$. 2014.

[3] Julien H, Given L M. Faculty-librarian relationships in the information literacy context: A content analysis of librarians' expressed attitudes and experiences[C]/Proceedings of the Annual Conference of CAIS/Actes du congrès annuel de l'ACSI. 2013.

[4] Sayed Y, De Jager K. Towards an investigation of information literacy in South African studentsl[J]. South African Journal of Libraries and Information Science, 2014, 65(1).

[5] Lohmann S. Threshold Concepts, Information Literacy, and Public Services Practice [J]. Public Services Quarterly, 2015, 11(3): 201-207.

[6] Leung L, Lee P S N. The influences of information literacy, internet addiction and parenting styles on internet risks [J]. New Media \& Society, 2012, 14(1): 117-136.

[7] Limberg L, Sundin O, Talja S. Three theoretical perspectives on information literacy [J]. Human IT: Journal for Information Technology Studies as a Human Science, 2013, 11(2).

[8] Higgins S, Gregory L. Information literacy and social justice: Radical professional praxis [M]. Library Juice Press, 2013. 